\title{
VEGETATION HISTORY AND CLIMATE BEFORE THE MAXIMUM OF THE LAST GLACIATION AT CROTTY, WESTERN TASMANIA,
}

\author{
by Eric A. Colhoun and Guus van de Geer
}

(with two text-figures)

COLHOUN, E.A. \& VAN DE GEER, G., 1987 (30:vi): Vegetation history and climate before the maximum of the last glaciation at Crotty, western Tasmania. Pap. Proc. R. Soc. Tasm., 121: 69-74.

https://doi.org/10.26749/rstpp.121.69 ISSN 0080-4703. Department of Geography, University of Newcastle, N.S.W. 2308 (E.A.C.); and Department of Geography, University of Tasmania, G.P.O. Box 252C, Hobart, Tasmania 7001 .

Organic-rich sands and silts estimated to be about 25000 to 40000 years in age indicate that alpine-subalpine herb, shrub and heath vegetation communities occurred at $250 \mathrm{~m}$ altitude in the King Valley prior to the maximum phase of the Last Glaciation. Mean temperature was probably $5^{\circ} \mathrm{C}$ colder than at present and the climate was wet.

Key Words: Vegetation history, climate, Pleistocene, Tasmania.

\section{INTRODUCTION}

During construction of Crotty Road in the King Valley of western Tasmania the HydroElectric Commission exposed a small section of organic-rich deposits on the eastern side of the road $3 \mathrm{~km}$ south of the junction with the Lyell Highway (fig. 1). The deposits occur at an altitude of $250 \mathrm{~m}$ a.s.l. in a small hollow and consist of bedded organic silts, sands and small gravels of $10-30 \mathrm{~mm}$ diameter. They underlie sandy fibrous peat and fragmented quartzite deposits, and rest on outwash gravels and till that belonged to the Comstock Glaciation, the Penultimate glaciation of the King Valley (Kiernan 1983). By analogy with many other exposures in the region, the sandy fibrous peat is interpreted as being of Holocene age. The fragmented quartzite deposits lie south of the limits of the Last or Margaret Glaciation and are interpreted as having been formed by frost shattering of surface gravels from the Comstock age glacial deposits that moved downslope over the organicrich deposits during the maximum stage of the Last Glaciation (about 25000-10000 yr b.p.). It, therefore, seemed that the underlying organic-rich deposits would reveal, through pollen analysis, the nature of the vegetation that occurred in the middle King Valley prior to the ice attaining its maximum extent in the West Coast Ranges during the Last Glaciation.

This paper records the environment and stratigraphy of the site, and describes the results of the pollen analysis. The deposits were sampled at $0.05 \mathrm{~m}$ intervals, and the samples were prepared by the method of Faegri \& Iversen (1975). A sum of

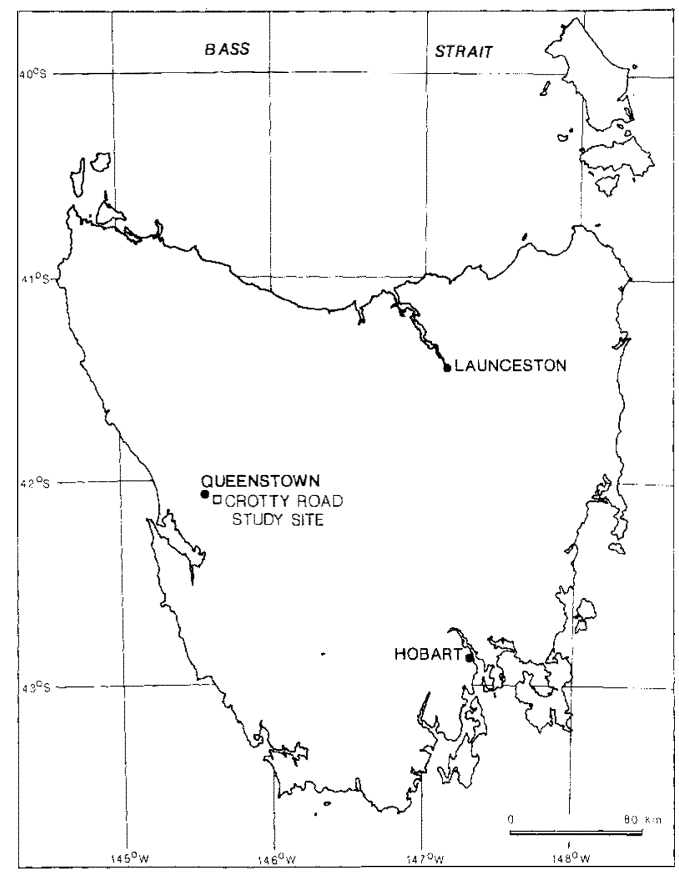

FIG.1 - Location of Crotty Road site, western Tasmania.

300 grains of dry-land taxa was used where possible, and sedges were omitted from the sum. The taxonomic nomenclature follows Curtis (1963, 1967), Curtis \& Morris (1975), Willis (1970), and Wakefield (1975). 


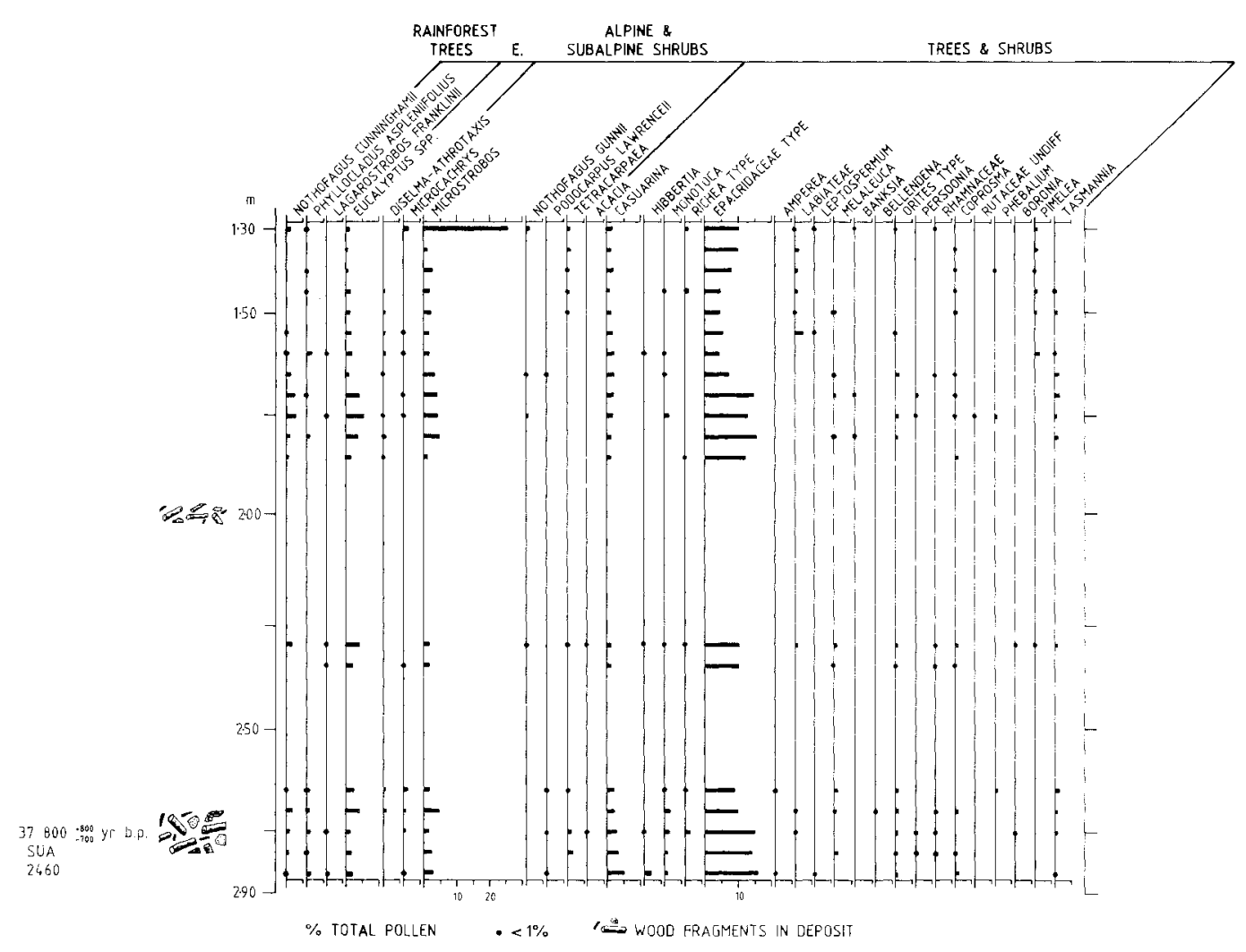

FIG.2 - Relative pollen diagram of Crotty Road organic-rich deposits.

\section{PRESENT ENVIRONMENT AND VEGETATION}

The site occurs at an altitude of $250 \mathrm{~m}$ on the western side of the King Valley in the lee of Mount Owen in the south-central part of the West Coast Ranges. Ordovician Owen Conglomerate and Cambrian volcanic rocks are exposed on the mountain slopes to the west and in the beds of the streams that cut through the glacial deposits. There is no reliable climatic data for the King Valley which being leeward of the mountains would be slightly drier than Queenstown with $2520 \mathrm{~mm}$ precipitation per annum. Winter mean temperatures of $7.1^{\circ} \mathrm{C}$ for July and summer mean temperatures of $14.8^{\circ} \mathrm{C}$ for January would be similar. Frosts and fogs associated with strong temperature inversions are common in winter. The gently undulating to sloping glacial moraine and outwash terrace deposits are very poorly drained and are covered with Holocene peat of 0.3 to $>1.5 \mathrm{~m}$ in thickness. Although potentially in a region of temperate Nothofagus cunninghamii rainforest vegetation, much of the valley floor is covered with epacridaceous heathland and Gymnoschoenus sphaerocephalus (buttongrass) sed geland, with wet scrub of Leptospermum scoparium, and Melaleuca squamea and $M$. squarrosa, and Eucalyptus simondsii forest on the better drained slopes of the hills. To what extent the heath, sedge and scrublands are products of soil water-logging and to what extent they are products of aboriginal and European firing is debatable, but firing during the late 19 th and 20 th centuries has certainly played an important part in their maintenance as non-forested areas (Kirkpatrick 1977, Kirkpatrick \& Dickinson 1984). 


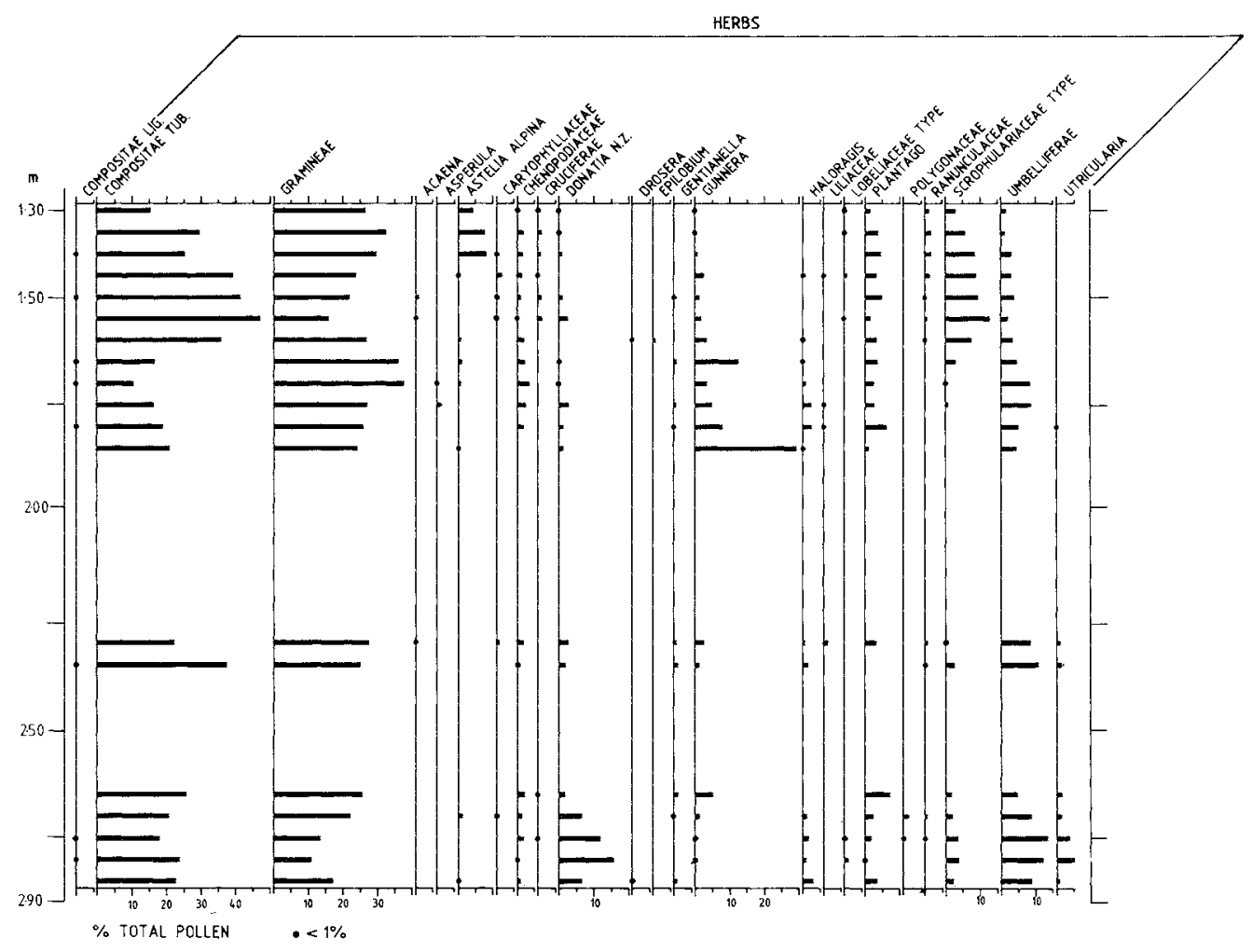

FIG. $2-($ Continued $)$

\section{STRATIGRAPHY AND DATING}

The stratigraphy of the small lake basin consisted of:

\section{Depth}

$0-0.50 \mathrm{~m}$

sandy peat

$0.50-1.50 \mathrm{~m}$ quartzite and $\mathrm{Owen}$ Conglomerate gravels, $10-100 \mathrm{~mm}$ in diameter, angular to sub-rounded in shape in an organic stained sandy matrix. Deposit poorly sorted.

$1.30-2.90 \mathrm{~m}$ bedded organic silts and sands, with abundant vertical rootlets of Restionaceae and drifted wood fragments at $2.00 \mathrm{~m}$ and at $2.70-$ $2.80 \mathrm{~m}$ depth. Rootlets and wood fragments are carbonised but no charcoal fragments were observed.
$2.90-3.50 \mathrm{~m} \quad$ glacial gravels of quartzite and conglomerate of $10-150 \mathrm{~mm}$ size. The gravels are poorly-sorted and bedded, but are moderately rounded.

$3.50->4.00 \mathrm{~m}$ till of Comstock glacial age which consists of quartzite, conglomerate and volcanic clasts, with frequent erratics of Jurassic dolerite and rare cobbles of Permian mudstone.

The entire thickness of lake sediments has been penetrated by humic acids derived from the surface peat deposits and heath vegetation.

Although not an ideal site for radiocarbon dating, one sample of well preserved wood (probably Leptospermum or Melaleuca) from 2.70$2.80 \mathrm{~m}$ depth gave a result of $37800+800 /-700 \mathrm{yr}$ 


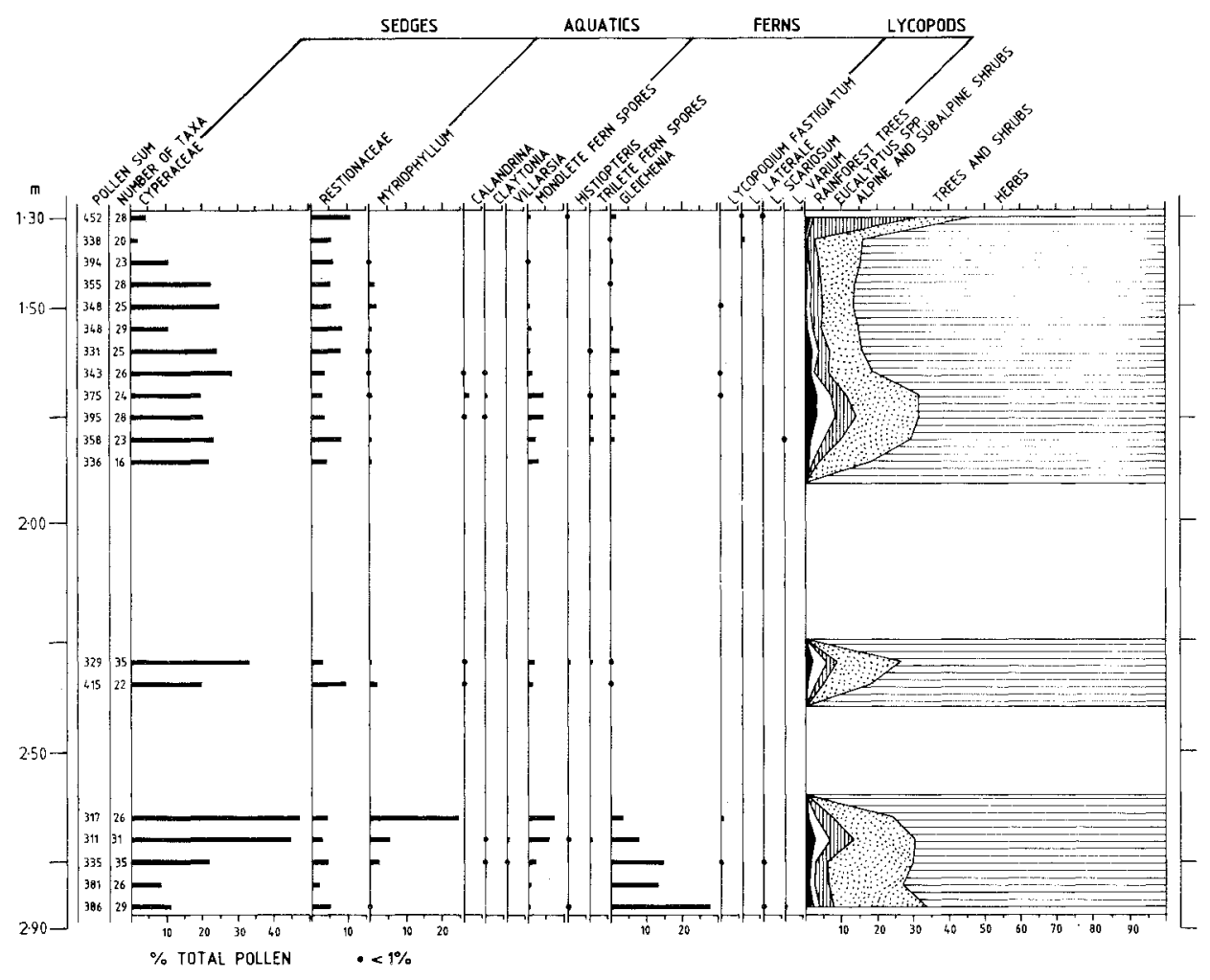

FIG. $2-$ (Continued)

b.p. (SUA 2469). The sample was pretreated with a 2:1 benzene:ethanol, then ethanol, then water, and cellulose was isolated with sodium chlorate. The result seemed to confirm that the base of the organic-rich lake deposit has a maximum age of about 40000 years. The interpretation of the stratigraphy presented suggests an approximate age of 25000 years for the top.

\section{THE POLLEN DIAGRAM}

The relative pollen diagram (fig. 2) shows that the vegetation consisted mainly $(70-80 \%)$ of herbaceous taxa. Woody taxa generally represent less than 20-30\% of the pollen. Alpine and subalpine taxa are generally about $5 \%$, and Eucalyptus spp. and rainforest taxa rarely attain $5 \%$. There is such uniformity in the whole profile that it cannot easily be divided into meaningful biostratigraphic zones, the pollen assemblages indicating that the sequence probably occurs within one zone. The nature of the vegetation communities that occurred in the area when the deposits accumulated is suggested by the constituent taxa.

Examination of a concentration pollen diagram not published here showed that concentrations fluctuated greatly from $10 \times 10^{3}$ to $350 \times 10^{3}$ grains/gm, the low concentrations being associated mainly with sandy sediments and the high concentrations with organic-rich sediments. The concentration values do not have markedly different peaks from the percentage values and merely confirm the relative degrees of importance of the plant groups to be described.

The very low quantities of the temperate rainforest taxa Nothofagus cunninghamii, Phyllocladus aspleniifolius and Lagarostrobos franklinii indicate that there was no extensive occurrence of lowland rainforest in the region. The low percentages are consistent with their having been 
produced by isolated pockets of rainforest trees/ shrubs in protected sites or by small stands close to treeline on the mountains. This rainforest component can be regarded as no more than background values for the pollen rain that could have been transported from other areas to the site. However, all Last Glacial age pollen diagrams from western Tasmania studied so far have shown a small component of rainforest pollen which seems to support the suggestion that small pockets or individual rainforest trees/shrubs were widespread (Colhoun 1985a, Colhoun \& van de Geer 1986, van de Geer et al. unpublished).

The very high herbaceous component dominated jointly by Gramineae and Compositae Tubuliflorae is also typical of diagrams from western Tasmania for the period preceding the maximum of the Last Glaciation (about 25000 to 40000 yr b.p.). The Gramineae and Compositae, together with other associated herbs and shrubs, indicate that the area was probably vegetated by a mosaic of alpine and subalpine herbaceous, shrub and heath communities such as would occur close to climatic treeline today.

The $5-10 \%$ of Astelia alpina in the upper part of the diagram indicates wet alpine to subalpine conditions while the $10-15 \%$ of Donatia novaezelandiae near the base of the diagram suggests alpine conditions. In addition, substantial quantities of pollen of Chenopodiaceae, Plantago, Ranunculaceae, Scrophulariaceae and Umbelliferae are common in diagrams from alpine and subalpine environments, while Gunnera and Gleichenia may also occur. Although the associated herbs point to the existence of a wet alpine-subalpine environment, it is known that these taxa can occur occasionally in the lowlands of southwestern Tasmania today providing there is no competition from scrub or forest vegetation (Kirkpatrick \& Duncan 1987). However, the pollen values are too high to be attributed to the isolated occurrences of plants or groups of plants and suggest that their occurrence was widespread.

The relatively large values for Microstrobos niphophilus, together with frequent DiselmaAthrotaxis and Microcachrys tetragona, and occasional Nothofagus gunnii and Podocarpus lawrenceii pollen, are also indicative of wet alpinesubalpine shrub communities. The high Epacridaceae T-type values could be either a product of subalpine vegetation or of wet heathland communities in association with Cyperaceae and Restionaceae. Although small quantities of Eucalyptus, Acacia and Casuarina pollen occur, which indicate the presence of sporadic trees, the values are too low to suggest the presence of woodland. The absence of the treeferns Dicksonia antarctica and Cyathea spp., of Atherosperma moschatum and Eucryphia-Anodopetalum type, and of Pomaderris apetala, Anopterus glandulosus, and Cenarrhenes nitida from the record clearly indicates that neither wet mixed forest nor wet sclerophyll forest occupied the floor of the King Valley during this period.

The data, therefore, seem to substantiate the initial suggestion that the valley floor was occupied by a number of alpine-subalpine herb, shrub and heath communities with occasional sclerophyll trees and rainforest trees/shrubs thinly scattered over the landscape. The associations point to a moist, cool environment that would be representative of near-treeline conditions today which occur at $1100 \mathrm{~m}$ altitude. If so, the treeline would have been lowered at least $850 \mathrm{~m}$ which implies an average temperature reduction of at least $5^{\circ} \mathrm{C}$. This value is $1.5^{\circ} \mathrm{C}$ less than that inferred from snowline data for the maximum phase of the Last Glaciation on the West Coast Range (Colhoun 1985b).

\section{COMPARISONS}

Interpreted as representing the period between about 25000 and $40000 \mathrm{yr}$ b.p., the pollen assemblages are very similar to those represented in the Henty Bridge diagram which is dated from about 20000 to $>35000 \mathrm{yr}$ b.p. and to Zone 3 of the Tullabardine Dam diagram which is dated from about 25000 to 50000 yr b.p. (Colhoun 1985a, Colhoun \& van de Geer 1986). They are also not very different from those of Zone 3 in a diagram from Newall Creek to the west of the West Coast Ranges which probably dates from about 25000 to $>40000$ yr b.p. (van de Geer et al. unpublished). The Crotty diagram, though showing that there was some spatial variability in the lowland plant communities represented in western Tasmania during the period that preceded the maximum phase of the Last Glacial Stage, indicates that the climate was cold and that most of the vegetation consisted of wet subalpine to alpine communities.

\section{ACKNOWLEDGEMENTS}

We thank Denis Charlesworth of the Department of Geography, University of Tasmania for preparing the pollen samples. We also thank Sharon Parry for typing the manuscript and Laurie Henderson for drafting the diagrams in the 
Department of Geography, University of Newcastle. We appreciated accommodation provided by the Hydro-Electric Commission of Tasmania at Crotty Camp.

\section{REFERENCES}

COLhouN, E.A., 1985a: Pre-Last Glaciation Maximum vegetation history at Henty Bridge, western Tasmania. New Phytologist, 100: 690-699.

COLHOUN, E.A., 1985b: Glaciations of the West Coast Range, Tasmania. Quat. Research, 24: 39-59.

COLHOUN, E.A. \& VAN DE GEER, G., 1986: Holocene to Middle Last Glaciation vegetation history at Tullabardine Dam, western Tasmania. Proc. R. Soc. Lond, B229: 177-207.

CURTIS, W.M., 1963 and 1967: THE STUDENT'S FLORA OF TASMANIA. Part 2 and Part 3. Government Printer, Hobart

CURTIS, W.M. \& MORRIS, D.T., 1975: THE $S T U-$ DENT'S FLORA OF TASMANIA. Part 1 , second edition. Government Printer, Hobart.

FAEGRI, K. \& IVERSEN, J., 1975: TEXTBOOK OF POLLEN ANALYSIS. Third edition. Munksgaard, Copenhagen.
KIERNAN, K.W., 1983: Weathering evidence for an additional glacial stage in Tasmania. Aust. Geogr. Stud., 21(2): 197-220.

KIRKPATRICK, J.B., 1977: The impact of man on the vegetation of the West Coast region. In Banks, M.R.\& Kirkpatrick, J.B. (Eds): $L A N D S C A P E$ $A N D M A N$. Royal Society of Tasmania, Hobart: 151-156.

KIR KPATRICK, J.B. \& DICKINSON, K.J.M., 1984: $M A P$ OF VEGETATION OF TASMANIA. Forestry Commission, Hobart.

KIRKPATRICK, J.B. \& DUNCAN，F., 1987: Tasmanian high altitude grassy vegetation: its distribution, community composition and conservation status. Aust. J. Ecol., 12: 73-86

VAN DE GEER, G., FITZSIMONS, S.J.\& COLHOUN, E.A.: Holocene to Middle Last Glaciation vegetation history at Newall Creek, western Tasmania. Unpublished.

WAKEFIELD, N.A., 1975: FERNS OF VICTORIA $A N D T A S M A N I A$. Field Naturalists Club of Victoria, Griffin Press, Adelaide.

WILLIS, J.H, 1970: A HANDBOOK OF PLANTS IN VICTORIA. Volume 1, second edition. Melbourne University Press, Melbourne.

(accepted 24 March 1987) 